\title{
Demand and Production Management Systematics for Optimizing the Fulfillment of Tempe Demand in MSMEs Mantab Rasa Madiun City
}

Chatarina Dian Indrawati ${ }^{1}$ Ardianus Laurens Paulus ${ }^{1}$ Petrus Setya Murdapa ${ }^{1}$

${ }^{1}$ Universitas Katolik Widya Mandala Surabaya Kampus Kota Madiun, Indonesia

\section{ARTICLE INFO}

Article history:

Received: 9th February 2021

Accepted: 20th September 2021

Published: 1st December 2021
Keywords:

Demand Management, MSMEs,

Soybean Tempe, Synchronization.

\begin{abstract}
Mantab Rasa Madiun is a home-based business in the city of Madiun that manages and supplies soybean tempe products with a capacity of 150-200 kg of soybeans per day. Providing product availability in the market is quite a complicated issue for Mantab Rasa, especially for food products that have a perishable product life. The delay in conveying information to the production department causes the accuracy of the production quantity to be unsuccessful so that many requests cannot be fulfilled or products that are not absorbed. Strategies to solve the problem include the formulation of a method of identifying market demand per day so that the response of the production section to meet demand is almost accurate. The method offered is to collect demand data from sales through the WA group so that the demand data can be centralized and easy to enter into the forecasting application formulation of demand data then forecast with an MS Excel-based application. From the forecasting results, it is then included in the MRP-Like time phasing formula with the aim that operational managers can more easily decide how many $\mathrm{kg}$ of raw and soaked soybeans to boil today. The systematics that has been made has been socialized to partners and tested for 7 days. The results obtained are the managers have a recapitulation of centralized daily demand data and quickly get a decision on how much soybeans are processed to meet demand.
\end{abstract}

How to cite: Dian Indrawati, C., Paulus, A. L., \& Murdapa, P. S. (2021). Demand and Production Management Systematics for Optimizing the Fulfillment of Tempe Demand in MSMEs Mantab Rasa Madiun City. Jurnal Pemberdayaan Masyarakat Madani (JPMM), 5(2), 171-188. https://doi.org/10.21009/JPMM.005.2.01

* Corresponding Author. 


\section{Jurnal Pemberdayaan Masyarakat Madani Volume 5 No 2 December 2021}

\section{INTRODUCTION}

The community service activities conducted by UKWMS the Madiun City Campus to the UMKM partners, namely Mantab Rasa Madiun, were beneficial. UMKM Mantab Rasa is a home industry whose activities are processing soybeans into tempeh under the brand "Murni" and peanuts into chili sauce under the brand "Mantab". About 90\% of sales turnover at UMKM Mantab Rasa is obtained from soybean tempe products "Murni". The average amount of soybean raw material processed is between 100$200 \mathrm{~kg}$ per day. UMKM Mantab Rasa Madiun is owned by the family of the couple R.Y. Wagiyo and M.G. Gumini. Mrs. M.G. Gumini manages the daily operation of the factory.

The tempe is distributed to markets and vegetable or food stalls in various corners of the city of Madiun. The soybean tempe produced by Mantab Rasa Madiun is given the brand name "Tempe Kedelai Murnui". There are three types of product variants provided, namely those weighing 200, 400 and 600 grams.

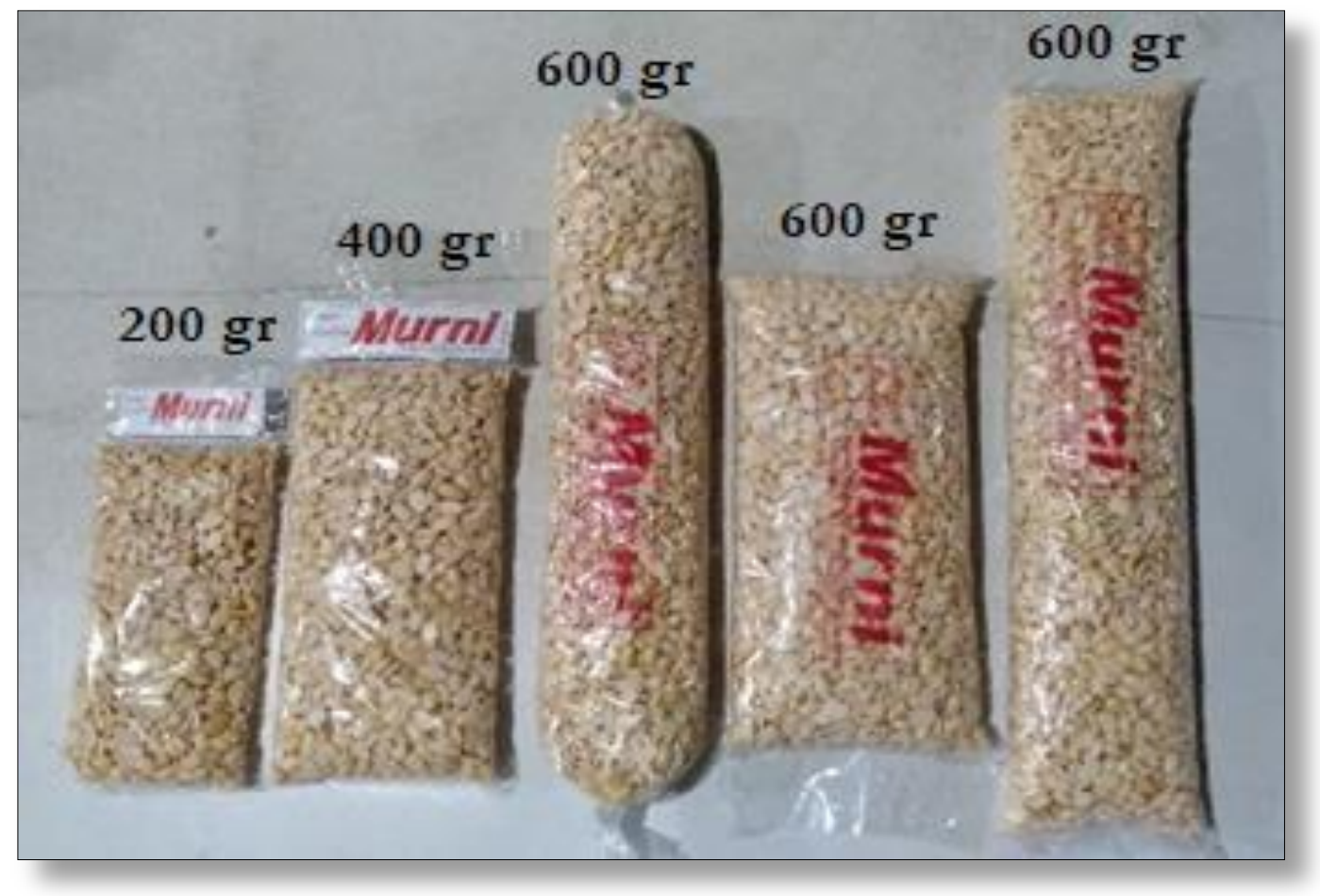

Figure 1.

Soybean Tempe Products "Murni" (Not fully fermented)

(Source: Observation Results) 


\section{Jurnal Pemberdayaan Masyarakat Madani Volume 5 No 2 December 2021}

Tempe made from soybeans has become a daily consumption in the community as a side dish or snack when relaxing. Food entrepreneurs or the general public will buy raw tempeh products regardless of who the producer is. For consumers, all tempeh will taste the same. They tend to pay more attention to the price per unit. Another thing is its availability in the market. Nasution, et al. (2008: 31) states that the factors that influence demand result from various interacting factors in the market, including: (1) Business Cycles. Product sales will be influenced by demand, and demand will be influenced by economic conditions that shape the business cycle with phases: inflation, recession, depression, and recovery. (2) Product Life Cycle. The life cycle of a product usually follows a pattern known as a sigmoid curve. The curve illustrates the amount of demand over time, where the life cycle of a product will be divided into the introduction, growth, maturity, and finally, the decline phase. To maintain business continuity, it is necessary to make certain innovations at the right time. (3) Other factors. Several other factors that influence demand are the backlash from competitors, changing consumer behavior, and its efforts, such as improving quality, service, advertising budgets, and credit payment policies.

According to Rehg (1994: 8), order winning criteria can provide an overview that the factory can translate market demand requirements for products into process choices and infrastructure requirements. The variables included in the order winning criteria include price, quality, lead time delivery or reliability, flexibility, ability to innovate, and leadership abilities (Regh, 1994: 9). Hence, the order winning criteria that Mantab Rasa Madiun must have based on people's perceptions of tempe products are (1) price, (2) availability in the market, and then (3) quality. Providing product availability in the market is quite a complicated issue for Mantab Rasa, especially for food products with a short product life, namely tempeh. This product cannot be in stock for a long time. Although the price is in the first place in the order winning criteria, the main problem faced by Mantab Rasa at this time is how to identify the amount of tempe demand in the market as a basis for setting production targets daily so that availability in the market can be met properly and products that are not absorption can be minimized. If this can be overcome, then competitive prices can be achieved.

Efforts to identify the demand for soybean tempe "Murni" produced by UMKM Mantab Rasa Madiun have been carried out, but the data obtained are always late. Requests occur dynamically. Officers need a lot of time to update information or make conclusions about the information. The delay in conveying information to the production department causes inaccurate determination of the quantity produced. This causes many requests that cannot be fulfilled, or on other occasions, a lot of production remains are not absorbed. In the end, the costs to be borne per unit of tempe produced will be greater. 


\section{LITERATURE REVIEW}

a. Management of Micro, Small and Medium Enterprises

Research conducted by Supeni and Sari (2011) with the subject of micro, small and medium enterprises (UMKM) concluded that there are four aspects in the management of UMKM, namely:

1. Finance. The management of their business finances is still straightforward, and they cannot separate business finances from personal finances.

2. Production or operational. During their development, they experienced various obstacles in terms of technical, technological, and production planning. On the other hand, creativity in creating new products is still minimal.

3. Marketing. The marketing scope of UMKM is still very limited in their environment (local market). Besides, people's purchasing power is still deficient, so the product's selling price must be below. It is easy for consumers to switch to competitive products that are cheaper.

4. Human resources. Human resources are still poorly educated, so their abilities and insights are still low.

Those are also the problem faced by UMKM Mantab Rasa. Thus, this team's community service activities are more focused on solving production or operational problems, especially on managing demand to allow the production amount to be designed to be close to the demand. That is, how can the amount of daily production be determined accurately and easily?

Managing UMKM requires high creativity, a feeling of not giving up quickly, having the courage to take risks, and always trying to find new things to improve performance. Tambunan (2002) states that SMEs that have a competitive advantage are UMKM that: have good quality human resources, make optimal use of technology, can make efficiency and increase productivity, can improve product quality, have broad promotion access, have a structured quality management system, has adequate capital resources, has an extensive business network, and has an entrepreneurial spirit. Based on these things, in this community service activity, the team socialized the use of software technology, namely the MS Excel application, to manage demand data and forecast demand for the next day to determine the amount of production that can be made more measured.

b. Demand Management

Product design activities, material purchasing, production, and delivery are carried out to meet the customer's needs or requests for goods or services. In almost all real situations, it is not easy to know the size and timing of the demand for goods or services before they occur. On the other hand, many activities must be done before the customer's request, or need is identified with certainty.

There are several types of products based on how demand is met. Among them are the make-tostock and make-to-order systems (Pujawan and Mahendrawathi, 2017). In the make to the stock system, the company will produce and store inventory until the finished product stage and delivery 
of goods is made based on orders from customers. In the make-to-order system, storing inventory is up to the semi-finished product stage or even in the form of raw materials for the production process to be carried out at any time when there is a demand. In the make to the stock system, the determination of the production amount is carried out based on the forecast of demand. The product can be available before a definitive request comes from the customer.

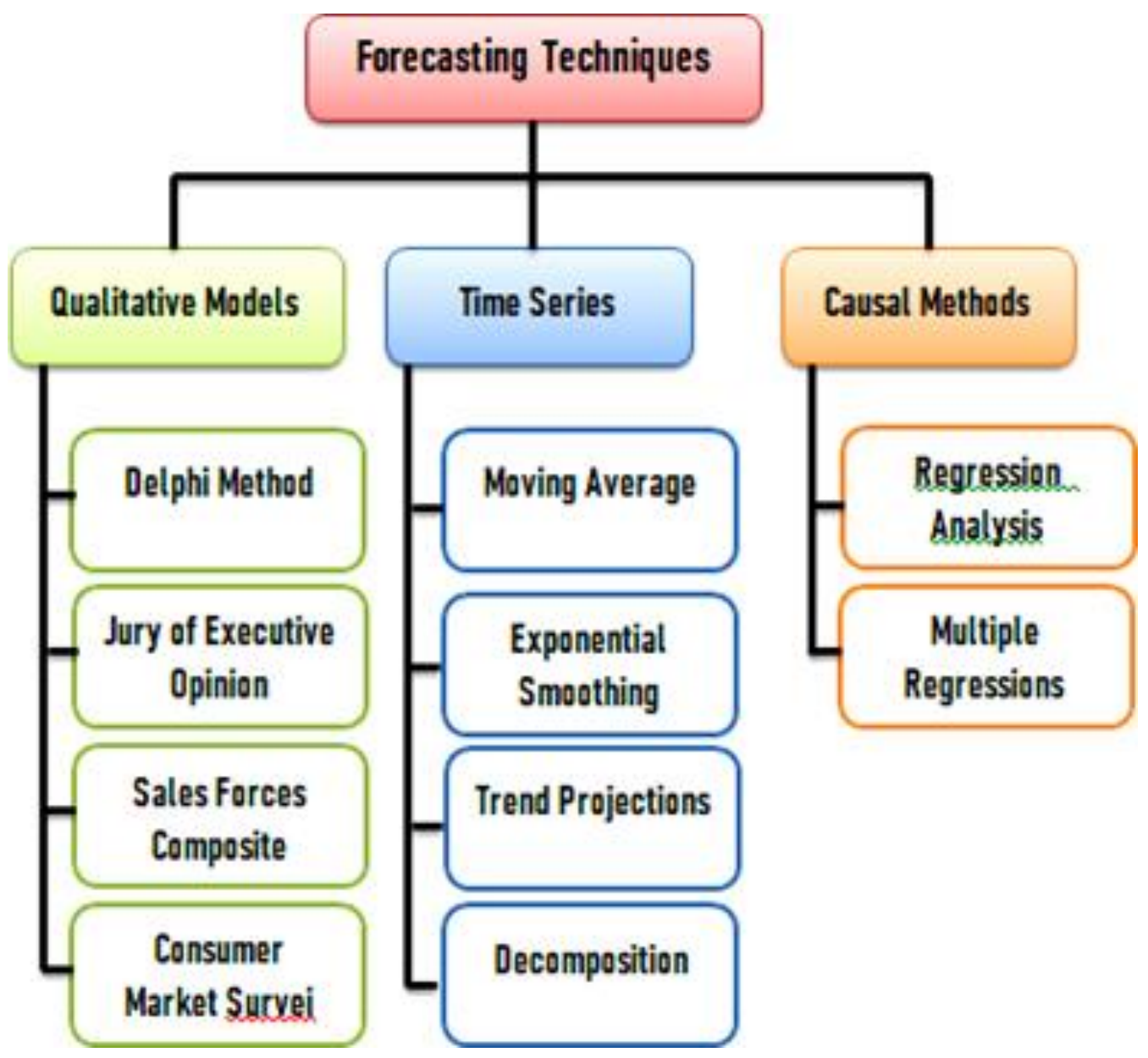

Figure 2.

Forecasting Methods

(Source: Render et al, 2015) 


\section{Jurnal Pemberdayaan Masyarakat Madani Volume 5 No 2 December 2021}

Demand forecasting is an activity to estimate the amount of demand for certain goods or services in a certain period and marketing authority (Pujawan and Mahendrawathi, 2017). Forecasting accuracy plays an important role in making product availability decisions. Increasing accuracy can be done by using better forecasting methods, searching for more comprehensive data, and selecting the right aggregation level. Common methods used in the forecasting process are shown in Figure 2. In UMKM, forecasting activities are carried out subjectively based on intuition and years of experience.

c. Material Requirement Planning

Material Requirement Planning (MRP) is a technique used for planning and controlling items (components) that are dependent on items at a higher level (Hartini, 2011; Murdapa and Indrawati, 2020). The MRP method is a Computer Oriented Approach consisting of a set of procedures, decision rules, and recording mechanisms designed to describe a Master Production Schedule (MPS).

To build an MRP system, at least three pieces of information are needed, namely: (Hartini, 2011, Murdapa and Indrawati, 2020):

1. Master Production Schedule (MPS), a production plan that describes the relationship between the quantity of each type of final product desired and its time. This Master Production Schedule is obtained from the results of demand forecasting by calculating a good production planning stage.

2. Bill Of Materials (BOM), a list of all materials, parts, and subassemblies, along with the quantity of each required to produce one parent assembly unit.

3. Inventory Master File is information on the amount of inventory for each component in each period, the number of items being ordered, and the time to square off.

The three inputs form archives interconnected with the production and purchasing departments to produce the latest information about ordering, receiving, and releasing components from the warehouse. After the three inputs are available, the system can perform the MRP calculation process according to production needs. The MRP calculation output is the determination of the number of each of the items required along with the date required. This information is used to plan an order release for the required components' purchase and/or production process. 


\section{MATERIAL AND METHOD}

The essence of management is regulation. Applying the arrangements at the UMKM Mantab Rasa can provide a fairly good solution. These settings are more on:

a. Planning

1. Understand partner complaints

2. Identify and evaluate order acceptance patterns - the method of determining production quantities (currently applied)

3. Develop a system for receiving orders and determining production

4. Simulate the designed system with data from partners

b. Organizing

1. The team communicates with partners regarding the planned system

2. Demonstrating the planned system to partners

3. Promote the system for receiving orders to sales

4. Socialize the method of determining the amount of production to the production department

5. Organize job descriptions based on a planned system

c. Supervision and Control

1. Testing the system for receiving orders on partners for seven days

2. Evaluate the trial results

3. Solve problems that arise from the results of the trial.

The management concept is implemented in activity management by analogy with the MRP system. Figure 3 provides an example of the MRP system analogy concept for determining the total daily production amount (in this paper, it is called MRP-like time phasing). 
NAME and ADRESS of CustCMER: Depor Gorengan Bu Marto, din Mundu 300

\begin{tabular}{|l|c|c|c|c|c|c|c|c|}
\cline { 2 - 8 } \multicolumn{1}{c|}{} & 1 & 2 & 3 & 4 & 5 & 5 & 7 & 8 \\
\hline Delivery demand & & & & & 15 & & 15 & \\
\hline Scheduled delivery & & & & 10 & & & & \\
\hline Projected stock & & & & & 0 & & 0 & \\
\hline Net delivery demand & & & & & 5 & & 15 & \\
\hline Planned delivery receipt & & & & & 5 & & 15 & \\
\hline Planned delivery reilease & & & & 5 & & 15 & & \\
\hline Planned production end & & & & 5 & & 15 & & \\
\hline Planned production start & & & 5 & & 15 & & & \\
\hline
\end{tabular}

NAME and ADRESS of CUSTOMER: Depot Pecel Bu Bejo, Jin Durian 300

\begin{tabular}{|l|c|c|c|c|c|c|c|c|}
\cline { 2 - 9 } \multicolumn{1}{c|}{} & 1 & 2 & 3 & 4 & 5 & 5 & 7 & 8 \\
\hline Delivery demand & & & 20 & & 20 & 10 & 20 & \\
\hline Scheduled delivery & & 10 & & & & & & \\
\hline Projected stock & & & & & & & & \\
\hline Net delivery demand & & & 20 & & 20 & 10 & 20 & \\
\hline Pianned delivery receipt & & & 10 & & 20 & 10 & 20 & \\
\hline Pianned delivery release & & 10 & & 20 & 10 & 20 & & \\
\hline Planned production end & & 10 & & 20 & 10 & 20 & & \\
\hline Pianned production start & 10 & & 20 & 10 & 20 & & & \\
\hline
\end{tabular}

TOTAL:

\begin{tabular}{|l|c|c|c|c|c|c|c|c|}
\cline { 2 - 9 } \multicolumn{1}{c|}{} & 1 & 2 & 3 & 4 & 5 & 6 & 7 & 8 \\
\hline Planned production start & 10 & & 25 & 10 & 35 & & & \\
\hline
\end{tabular}

Figure 3.

MRP-Like Time Phasing 


\section{RESULT AND DISCUSSION}

The soybean tempe product "Murni" consists of several packages, namely 200 grams (one variant), 400 grams (one variant), and 600 grams (three variants). In Figure 4, soybean tempe "Murni", which is still in the form of soybeans, is arranged on a shelf for the fermentation process for 34-36 hours so that it becomes ready to cook.

Before being put into the soybean cooking process, the soybean seeds are separated from soil impurities, corn kernels and dry twigs, followed by splitting soybean seeds. The soybean seeds are sorted and broken in raw conditions to be separated from the outer layer at once. Cracking is done using a crusher that mechanically breaks the soybeans and peels off the outer layer and ejects it into a different location. Then sorted again to separate the remaining outer layer.

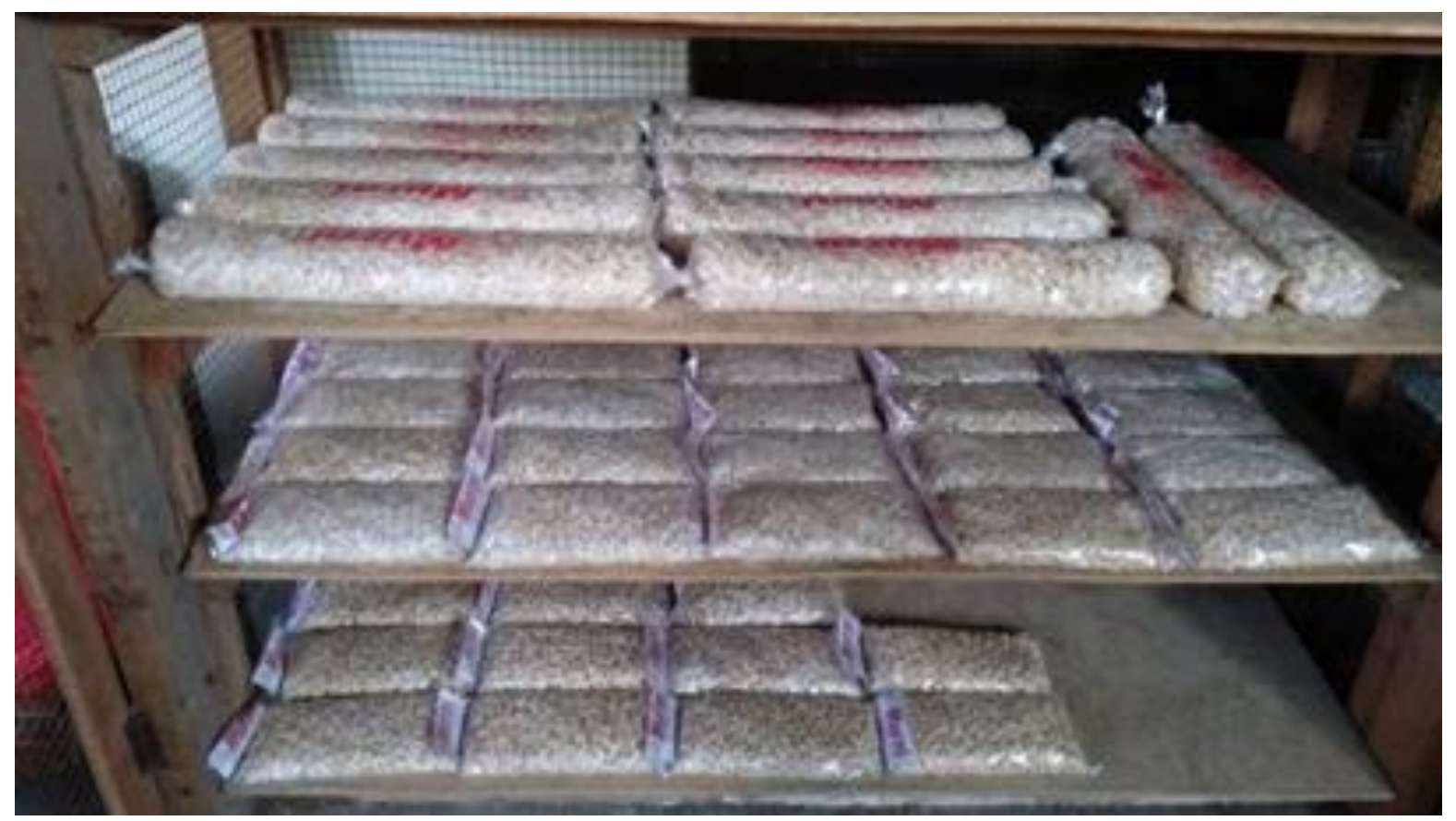

Figure 4.

Soybean tempe arranged on the shelf for fermentation

(Source: Observation Results) 


\section{A. Planning and Organizing}

At the planning stage, the team visited the partner's location to communicate related to the problems the partners were facing. From the interview, it is known that sales and order transactions occur to sales and consumers. The job of the salesperson (six people) is:

1. Deliver tempe,

2. Record the amount of tempe and the amount of money,

3. Collect sales money and receive payments from consumers,

4. Inquire order quantity or accept order quantity,

5. Submit sales reports, and order information for the next period, to the administration

Seven consumer types of soybean tempe "Murni" have different ordering ways, as shown in Table 1 below.

Table 1. Types of soybean tempe "Murni" consumers

\begin{tabular}{|c|c|c|c|c|c|c|c|}
\hline \multirow{3}{*}{ Type of Customer } & \multirow{3}{*}{$\begin{array}{c}\text { Number of } \\
\text { consumers } \\
\text { per day }\end{array}$} & \multicolumn{6}{|c|}{ Average total orders in 1 order period (unit) } \\
\hline & & \multicolumn{3}{|c|}{ Tempe fermented } & \multicolumn{3}{|c|}{$\begin{array}{l}\text { Tempe being } \\
\text { fermented }\end{array}$} \\
\hline & & Sentll & Modrim & Big & Small & Medinm & Big \\
\hline $\begin{array}{l}\text { Resellers in traditional } \\
\text { markets }\end{array}$ & 16 & so & 20 & 50 & 120 & 30 & 180 \\
\hline Reseller of vegetable sellers & 15 & 180 & 10 & 60 & 50 & & 50 \\
\hline $\begin{array}{l}\text { Food stalls / depots / } \\
\text { restaurants }\end{array}$ & 10 & 50 & & 50 & 20 & & \\
\hline Hospital kitchen & 1 & 25 & & & 20 & & \\
\hline Dorm kitchen & 2 & & & 50 & & & \\
\hline Tempe chips manufacturer & 4 & & & 60 & & & 150 \\
\hline End consumer (household) & \pm 8 & 30 & & 10 & & & \\
\hline Total & & 365 & 30 & 280 & 210 & 30 & 380 \\
\hline
\end{tabular}

(Source: Observation Results) 
Table 1 above explains how each type of consumer places an order for soybean tempe "Murni". Previously there were several ways to order. This varied way of ordering is the source of the problem. However, some results of process trials provide several ways to extend the life of soybeans in the process or tempeh without reducing the quality as follows (charted in Figure 8):

1. Re-soak "white" soybeans before cooking to extend their lifespan by one day before cooking

2. Wrap the unfinished packaging tightly so that it can extend the life of the tempe by one day

3. Storing finished tempe (especially for large packaged tempe - 600 grams) in the refrigerator can extend temple's life by one day.

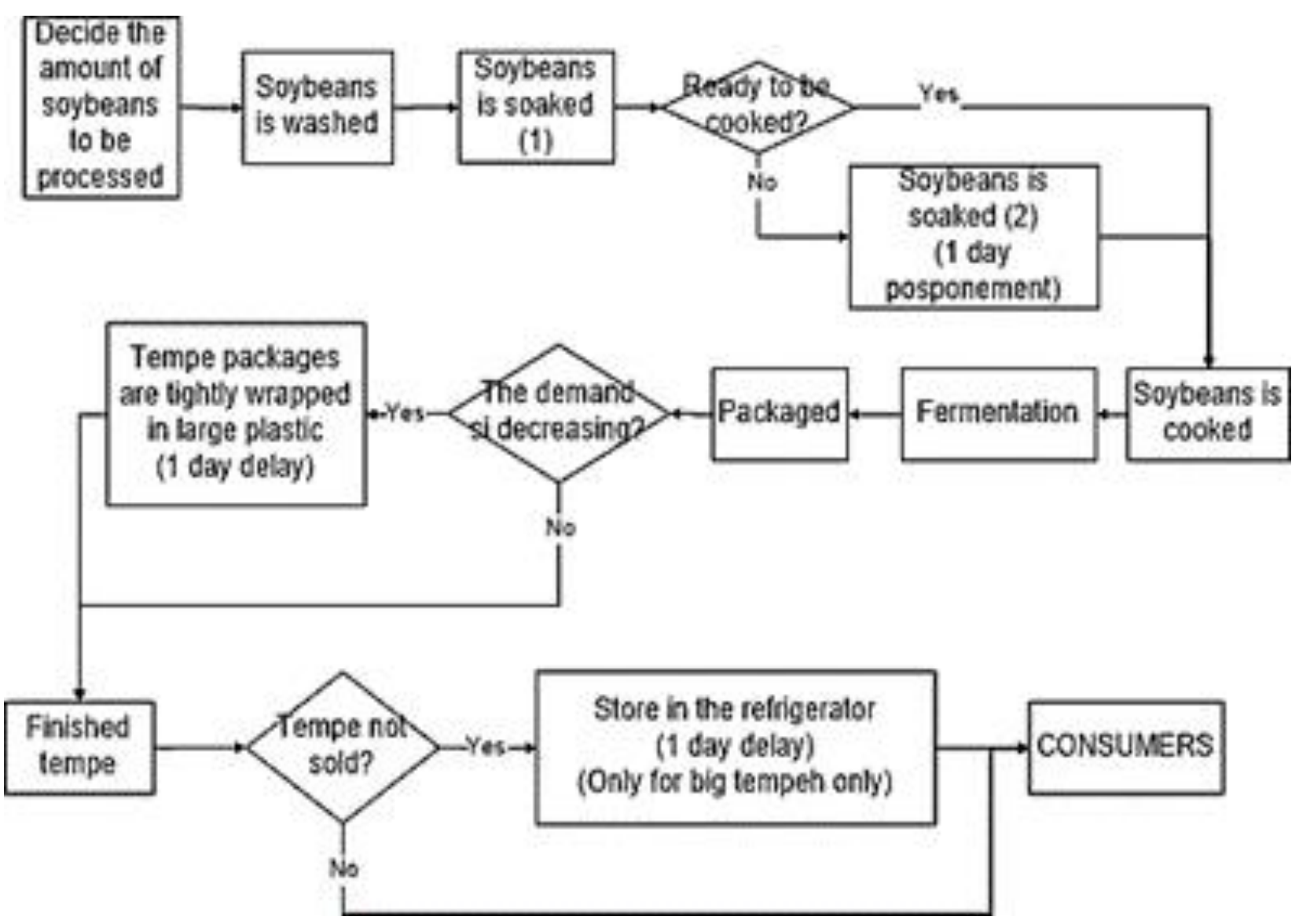

Figure 8.

Postponement method chart

(Source: Observation and Analysis Results) 


\section{Jurnal Pemberdayaan Masyarakat Madani Volume 5 No 2 December 2021}

The order method needs to be standardized so that order recapitulation can be made easier with certain systematics. The order submission system is designed to suppress/minimize lost sales by determining how many soybeans are cooked today. Soybean that must be cooked on this day consists of two forms, namely raw soybeans (referred to as "irengan" by the production department of the partners) and boiled soybeans (referred to as "putihan" by the production department of the partners).

The output from the order systematics allows the production department to more easily determine the number of soybeans cooked today, both "irengan" and "putihan" to respond to definitive consumer orders, and provide stock to fulfill orders that are not yet definitive.

Following the MRP (Material Requirement Planning) mechanism, the activity phases for receiving and fulfilling orders can be arranged in the form of Figure 3 above. Table 2 continues the concept in Figure 3 to explain the progress flow of the process from when the material is still raw material (soybeans) to when it becomes tempeh (for example there are three batches: one batch $\mathrm{A}=50 \mathrm{~kg}$, one batch $\mathrm{B}=70 \mathrm{~kg}$, and one batch. $\mathrm{C}=80 \mathrm{~kg}$ ).

Table 2. The time phase of the progress of the material conditions from soybeans to tempe

\begin{tabular}{|c|c|c|c|c|c|c|c|}
\hline \multirow{2}{*}{ Status } & \multicolumn{7}{|c|}{ Day } \\
\hline & 1 & 2 & 3 & 4 & 5 & 6 & 7 \\
\hline 1. Soybean "irengan" (raw) & 50 & 70 & 80 & & & & \\
\hline 2. Soybeans "irengan" is milled & so & 70 & 80 & & & & \\
\hline 3. Soybean "irengan" is sorted & 50 & 70 & 80 & & & & \\
\hline 4. Soybean "irengan" is boiled to be "putihan 1" & & 50 & 70 & 80 & & & \\
\hline 5. Soybean "putihan 1" is sorted & & 50 & 70 & 80 & & & \\
\hline 6. Soybean "putihan 1 " is soaked ( \pm 16 hours) & & 50 & 70 & 80 & & & \\
\hline $\begin{array}{l}\text { 7. Soybean "putihan } 1 \text { " is drained and then boiled } \\
\text { into "putihan } 2^{\text {" }}\end{array}$ & & & 50 & 70 & 80 & & \\
\hline 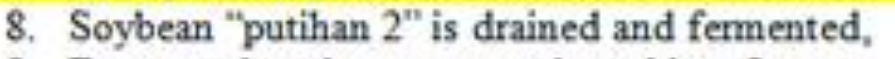 & & & 50 & 70 & 80 & & \\
\hline 9. Fermented soybeans are packaged into 3 types, & & & 10 & 10 & 15 & & \\
\hline large (600gr) packages and fermented for 36 - & & & 20 & 25 & 25 & & \\
\hline 39 hours. & & & 30 & 35 & 40 & & \\
\hline $\begin{array}{l}\text { 10. Finished tempe (in small, medium, and large } \\
\text { packs) }\end{array}$ & & & & & 50 & 70 & 80 \\
\hline
\end{tabular}

(Source: Observation and Analyais Results) 


\section{Jurnal Pemberdayaan Masyarakat Madani Volume 5 No 2 December 2021}

\section{B. Socializing, Trials, Supervision, and Control}

The socialization was given to two divisions of partner organizations, namely sales and production personnel. For the sales division, the topic of order acceptance and order reporting systematics was socialized. For the production division, the topic is the determination of production quantities. The socialization was carried out at partner locations.

The results obtained from this socialization were that salespeople were not familiar with the new way, namely reporting the number of orders via the messaging application, WA. Therefore, a sevenday trial was carried out to familiarize salespeople with reporting orders in writing and via WA.

Partners who manage daily production were used to intuitively determining the number of soybeans cooked each day. Initially, the MS Excel-based request management application was considered a hassle. Still, managers who were accompanied by younger production workers were finally able to understand the systematic procedure and run it.

After socialization, the systematics delivered were then tested for seven days, several obstacles were found, namely sales forgetting to report via WA regarding requests from customers. Indeed, salespeople are accustomed to writing manually reporting the nominal money received from customers' billing and reporting orders. However, after three days of testing, the new mechanism was running smoothly so that the salespeople then routinely used it to make order reports from customers. Data from sales can be recapitulated and included in the production forecasting process so that it is known the next day how many kg of raw and soaked soybeans will be cooked to meet the next demand.

The seven-day trial results were not enough to familiarize the sales and daily production managers with the new systematics. The team undertakes to provide partner assistance related to the systematics to apply it, especially in its benefits in making decisions on the amount to be produced. It is not only based on intuition.

\section{CONCLUSIONS AND RECOMMENDATION}

Community service activities that have been carried out have provided new insights for UMKM Mantab Rasa in getting a more systematic way when managing daily production. Partners who carry out dual responsibilities, namely in addition to leading UMKM and managing daily production, are quite helped by this new systematics. Indeed, this new method of refraction takes time to get used to and be smooth in implementation.

The team found that the activities carried out at the UMKM Mantab Rasa were sufficient to help carry out daily production because the mistake in determining the number of soybeans to be cooked could result in a shortage or excess of tempe stocks which were both economically unprofitable. Several treatments have been carried out for excess stock so that the tempe can be sold the next day or the fer- 


\section{Jurnal Pemberdayaan Masyarakat Madani Volume 5 No 2 December 2021}

mentation process can be postponed. At least with this systematics, the excess stock can be reduced significantly, and at the same time, the occurrence of stockout can be avoided as far as possible. Further activities.

\section{REFERENCES}

Hartini, Sri. (2011). Teknik Mencapai Produksi Optimal. Bandung: Lubuk Agung.

Murdapa, P.S. (2020). Metode Penjadwalan Operasional Produksi pada Sistem Produksi Job Shop dengan Basis Material Requirement Planning. Laporan Penelitian Tidak Diterbitkan. Madiun: PSDKU Rekayasa Industri, FT UKWMS.

Pujawan, Nyoman; Mahendrawathi. (2017). Supply Chain Management. Edisi 3. Jakarta: Guna Widya Render, Barry; Stair Jr, Ralph M.; Hanna, Michael E. (2015). Quantitative Analysis for Management, $12^{\text {th }}$ Edition. Inggris: Pearson.

Regh, J.A. (1994). Computer-Integrated Manufacturing. Prentice-Hall Inc, New Jersey.

Supeni, R.E. \& Sari, M.I. (2011). Upaya Pemberdayaan Ekonomi Perempuan Melalui Pengembangan Manajemen Usaha Kecil. Laporan Seminar Tidak Diterbitkan. Jember: Fakultas Ekonomi UNIMUS.

Tambunan, T. (2002). Usaha Kecil dan Menengah di Indonesia: Beberapa Isu Penting. Jakarta: Salemba.

\section{ATTACHMENT}

1. Soybean seed sorting and cracking
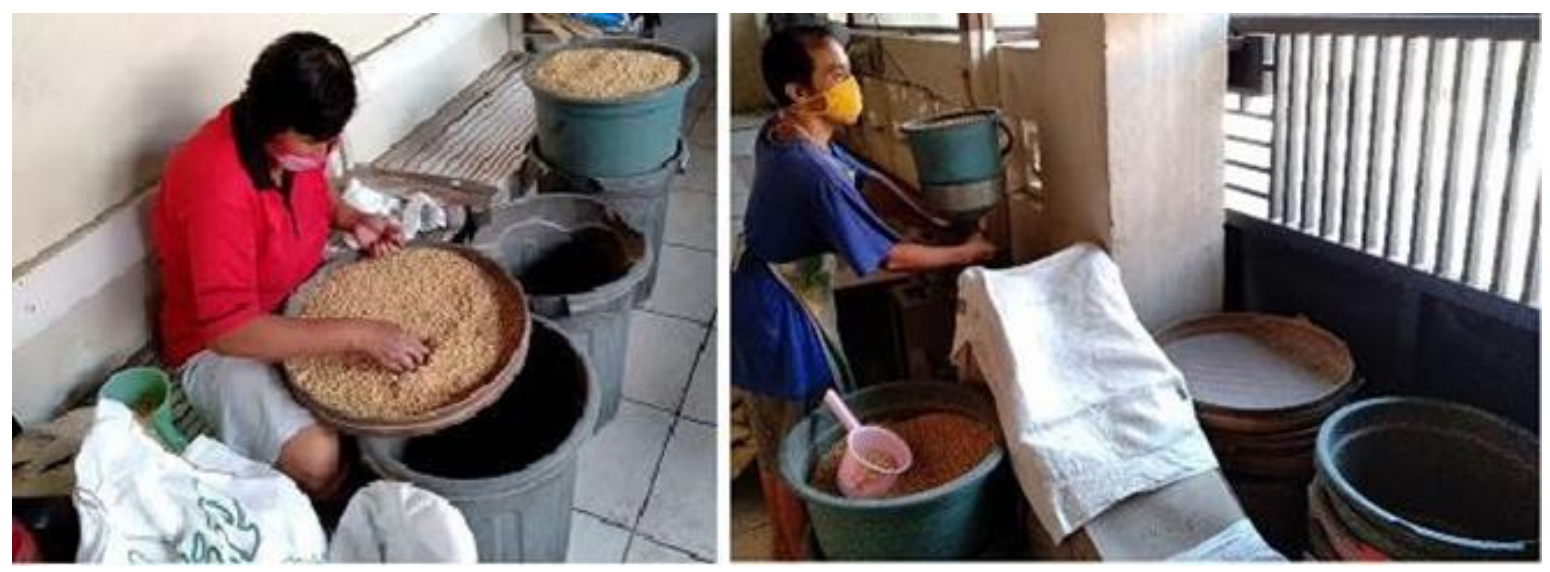
Jurnal Pemberdayaan Masyarakat Madani Volume 5 No 2 December 2021

2. Soybean tempe "Murni" cooking process

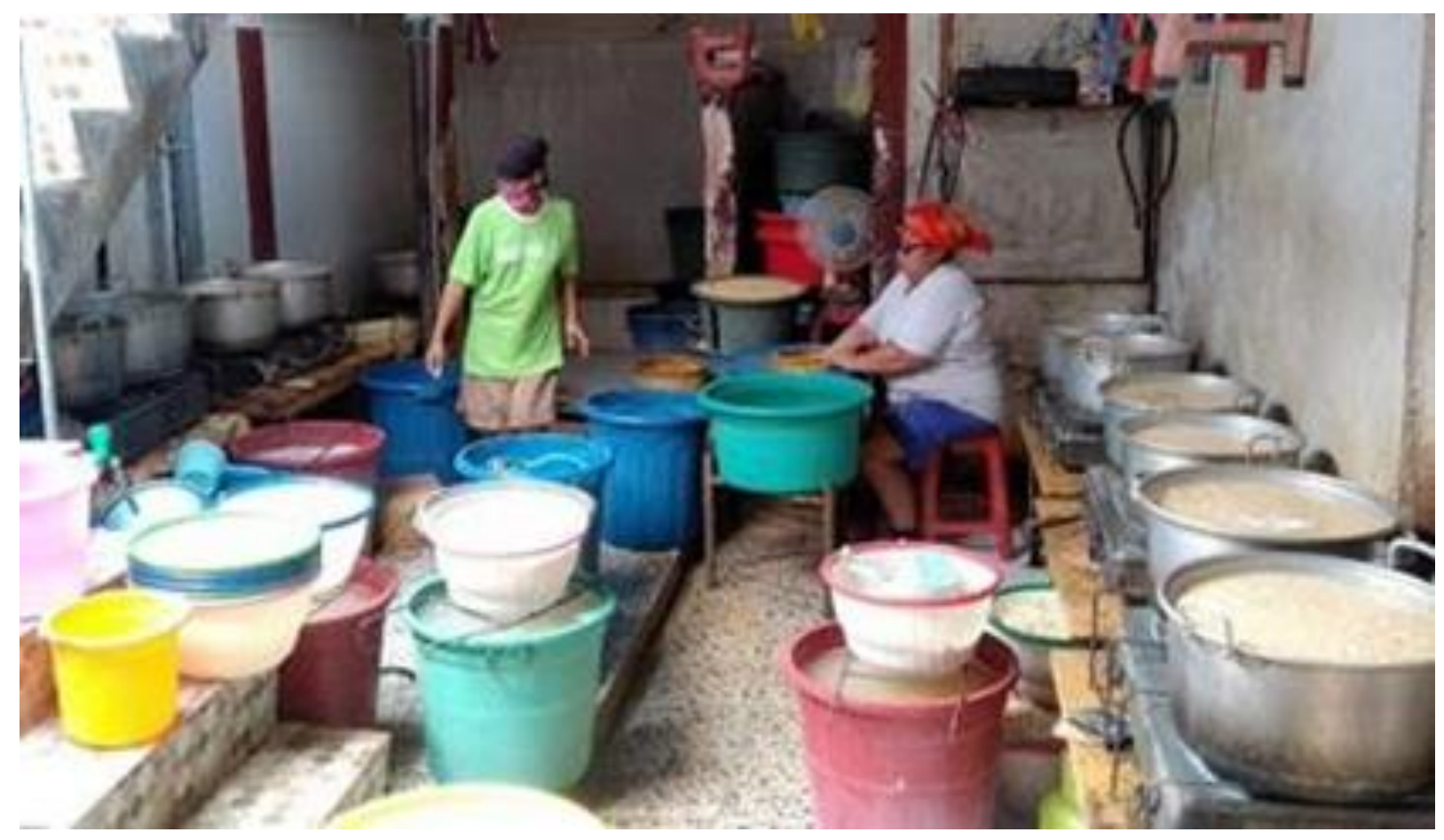


Jurnal Pemberdayaan Masyarakat Madani Volume 5 No 2 December 2021

3. Soybean tempe "Murni" packaging

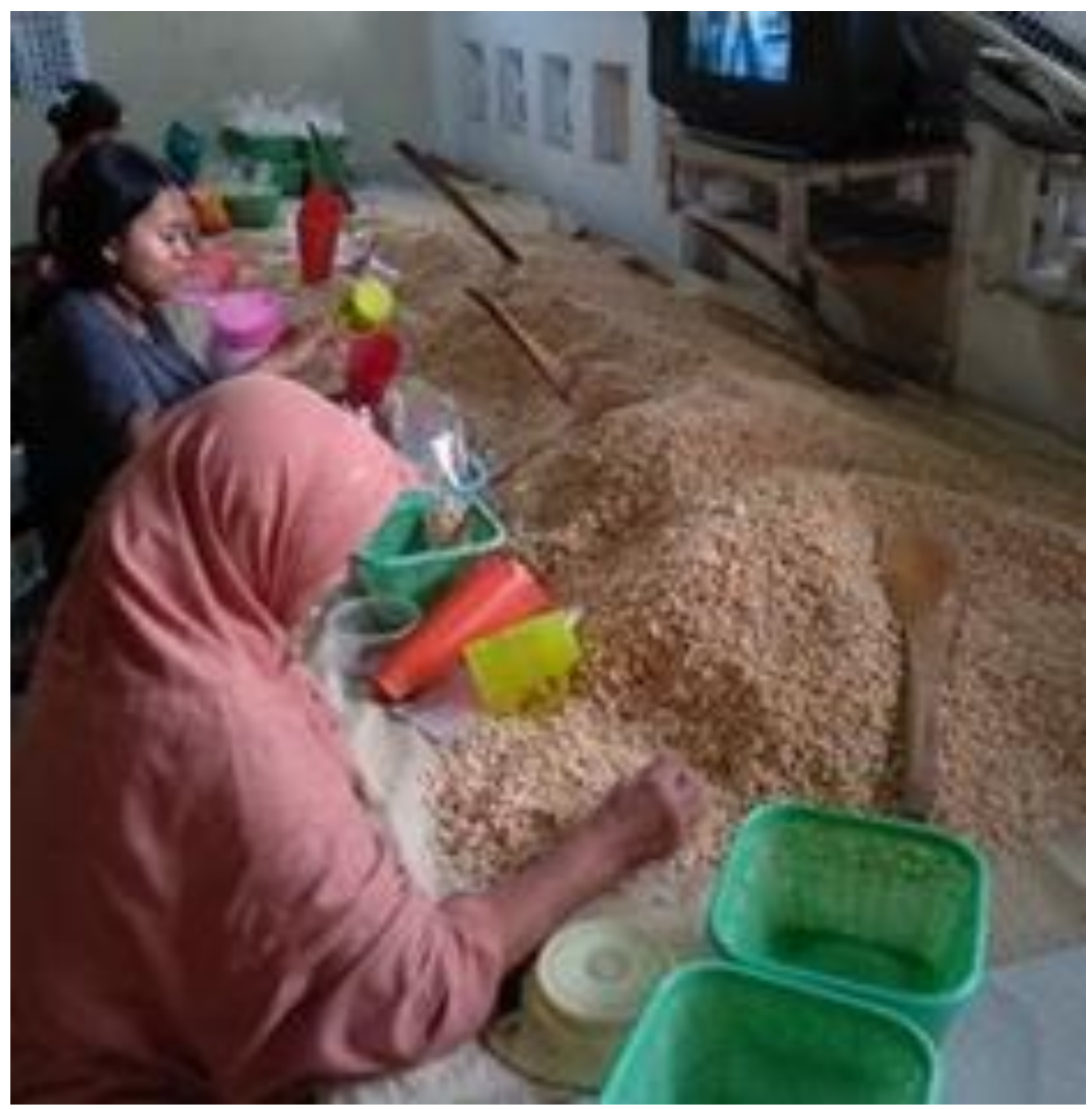

Dian Indrawati, C., Paulus, A. L., \& Murdapa, P. S., /

Jurnal Pemberdayaan Masyarakat Madani, 5 (2) 2021, 171-188. 
4. Socialization of Order Receipt and Reporting systematics

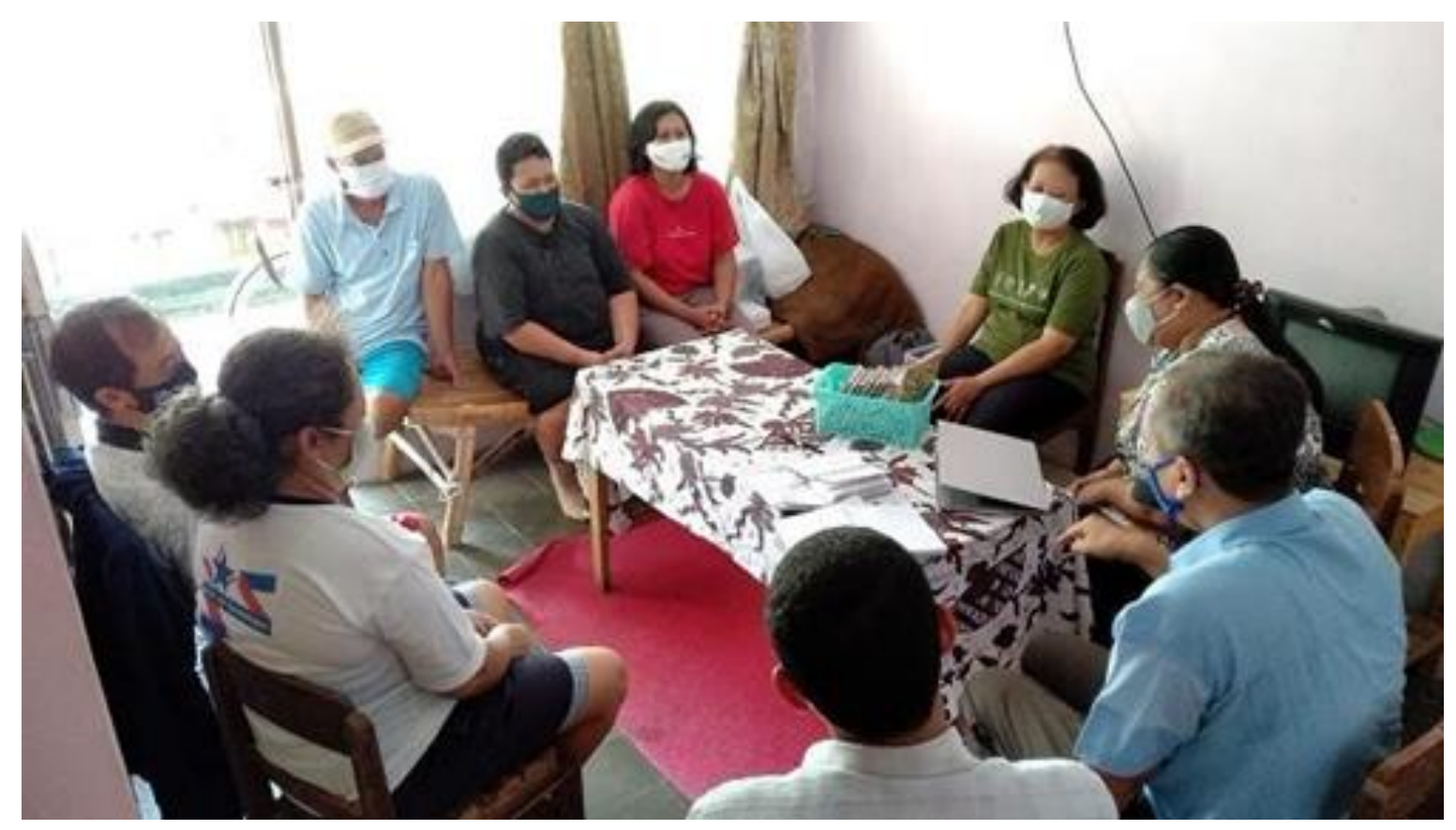




\section{Jurnal Pemberdayaan Masyarakat Madani Volume 5 No 2 December 2021}

5. Socialization of demand management systematics
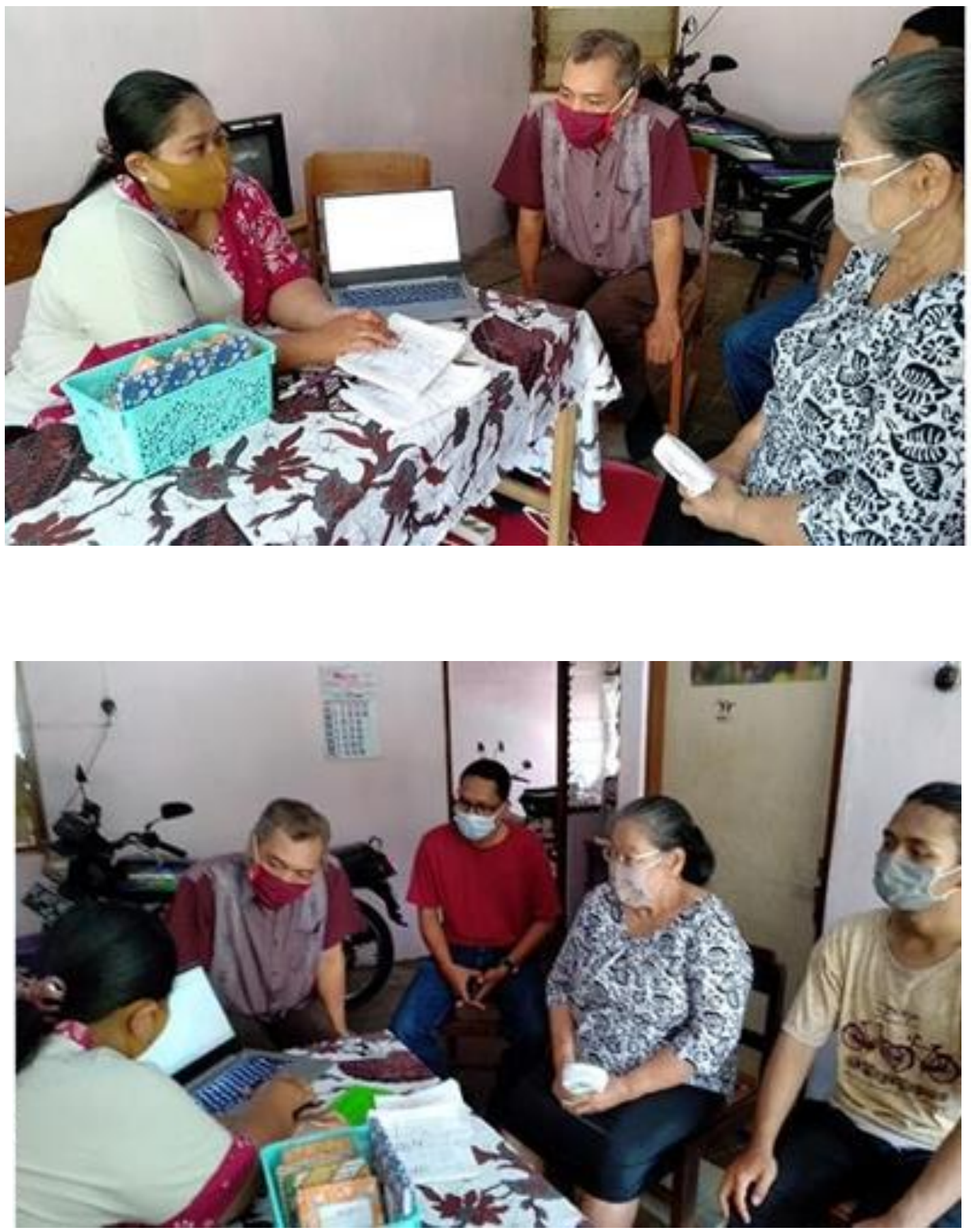